\title{
サプレッサーの切り替えによる陰陽イオンの選択検出 イオンクロマトグラフィー
}

\author{
丁 明玉 ${ }^{\circledR}$, 鈴木 義仁, 小泉 均*
}

(1992 年 12 月 14 日受理)

\begin{abstract}
陰イオン交換カラムと陽イオン交換カラムを直結し, 両カラムに適用できる低電気伝導度のシュウ酸 溶離液を用いて陰・陽両イオンの溶出特性を検討した後, 飲物中に含まれる有機酸と陽イオンの同時分 離を試みた，陰・陽両カラムを直結すると，陽イオン各々について 2 本のピークが現れた。陰・陽イ オンカラムの直結順序によって陽イオンの溶出クロマトグラムは異なる.ノンサプレッサー法を用いて, $\mathrm{Na}^{+}$と $\mathrm{NH}_{4}{ }^{+}$をほとんど含有していないワイン中の主要な有機酸と陽イオンと無機陰イオンは一斉分 離できるが, クロマトグラムには正負のピークが混在して, 定量処理は煩わしい. $\mathrm{Na}^{+}$と $\mathrm{NH}_{4}{ }^{+}$を含 有している日本酒のような飲物に応用するために，陰・陽両イオンをカラム分離した後に陰・陽イオン サプレッサーを連結し，サプレッサーの切り替えにより試料中の陰又は陽イオンのみを検出するように 工夫した。すなわち, 陽イオンを検出する場合にはサプレッサーに陰イオン交換膜型の陰イオンサプレッ サ一を作動させて，クロマトグラム上より陰イオンのピークを消失させる. 又陰イオンを検出する場合 には陽イオン交換膜型の陽イオンサプレッサーを作動させて試料中より陽イオンを除去して，陰イオン のみのクロマトグラムを得る。このようなサプレッサーの切り替えだけで, 溶離してくる陰及び陽イオ ンを簡便に選択検出できる方法を確立した。
\end{abstract}

\section{1 緒言}

イオンクロマトグラフィーは, 様々な試料, 特に生 物, 環境及び食品試料中のイオン性成分の迅速, 高感度 な分析方法として広範井に态用されている1) 3). 特に 導電摔検出器を用いる場合には, サプレッサーで分析目 的イオンの対イオンを系外に除去する方法で, 溶離液を 低電気伝導度化し, 高感度化を図っている. 陰・陽両イ オンを分析するためにはまず陰イオン分離用溶離液を用 いて陰イオンを分離定量した後, カラムと溶離液を交換 し, 改めて陽イオンの分離条件を設定する必要がある.

著者ら は低交換容量の陰イオン交換カラム(横河電 機製，SAM3-075）とフタル酸水素カリウム溶離液とを 用いて日本酒，ワイン，ジュースなどの飲物中の多種の 有機酸を分離することに成功した。しかし，これらの飲 物中には多くの有機酸や無機陰イオンと陽イオンが共存 している. そのため, 食品類の品質管理上で陰・陽両イ オンの簡便・进速な検出法の確立が要望されている.

迅速な猞・陽イオンの同時筀量を達成するためには以 下の一つの䦭題を解決する必要がある。一つは陰イオン

*山梨大学I学部化学生物工学科：400 山梨県甲府市武 田 4-3-11
の分離にも陽イオンの分離にも適用が可能な共通溶離液 を選定すること，もう一つは陰イオン分離カラムと陽イ オン分離カラムとの併用又は陰・陽両イオン交換樹脂を 混ぜた混合充てんカラムの開発である.

共通溶離液については, 多くの低電気伝導度の溶離液 を検討した結果, 著者らはシュウ酸溶液を溶離液とし, 陰及び陽イオンカラムを並列に接続し, 溶離液の流路を バルブで切り替えることにより, 溶離液組成などの分析 条件を変えることなく，陰・陽両イオンの分析を達成さ

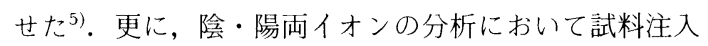
が1 回で済むプレカッティング (pre-cutting) 方法6)を 報告した。すなわち, 陽イオン交換カラムと陰イオン交 換力ラムを直列に配置し, 陰イオン交換カラムの前後に バルブを用いて分岐流路を構成した．陽イオン交換カラ ムに保持されない陰イオンを陰イオン交換カラム中に停 留させ, 陽イオンの分析が終了した後, 流路を切り替え て引き続き陰イオンを分離することにより，一つのクロ マトグラム上に陽イオンと陰イオンを検出することを可 能にした.

本研究では陰・陽両イオンをカラム分離した後に，市 販の陰イオンサプレッサー (陽イオン分析用) 之陽イオ ンサプレッサー (陰イオン分析用) を取り付け, サプレ 
ッサーの流路切り替えのみで，溶離液を変えることな く, 溶離してくる陰・陽両イオンの選択検出を行うこと により，迅速な陰・陽両イオンの分析が可能になった. 本法の応用として, 日本酒及びワイン中の有機酸と陽イ オンの同時定量を行った．以下にこれらの結果を記載す る.

\section{2 実験}

\section{$2 \cdot 1$ 試薬及び試薬溶液の調製}

有機酸は市販一級品を用いてそれぞれ 2000〜4000 $\mathrm{ppm}(\mu \mathrm{g} / \mathrm{ml})$ の原液を調製し, $\mathrm{HPO}_{4}{ }^{2-}$ と $\mathrm{Cl}^{-}$は市 販一級の無水リン酸二ナトリウムと塩化ナトリウムを用 いてそれぞれ $1000 \mathrm{ppm}$ の原液を調製した。陽イオンは $105^{\circ} \mathrm{C}$ で乾燥した特級塩化物を用いてイオン交換水でそ れぞれ $1000 \mathrm{ppm}$ の原液を調製した。必要に応じて，こ れらの原液を用いて種々の組成と濃度の陰イオン標準溶 液, 陽イオン標準溶液及び陰陽両イオンの混合標準溶液 を調製した．溶離液は市販一級のシュウ酸をイオン交換 水で所定濃度の溶液に調製した。除去液として, 陰イオ ンサプレッサーには $50 \mathrm{mM}$ 水酸化ナトリウム水溶液 を, 陽イオンサプレッサーには $10 \mathrm{mM}$ 硫酸水溶液を用 いた。

\section{$2 \cdot 2$ 装 置}

本実験に用いた装置の概略図を Fig. 1 に示した。装 置は電導度検出器付きのイオンクロマトアナライザー （横河電機製， IC-100）である。陰イオン交換力ラム (横河電機製, SAM3-075, $4.6 \mathrm{~mm}$ i.d. $\times 75 \mathrm{~mm}$ ) と陽 イオン交換力ラム（横河電機製, ICS-C25, $4.6 \mathrm{~mm}$ i.d. $\times 125 \mathrm{~mm})$ を直結した後に，二つのバルブを用いて

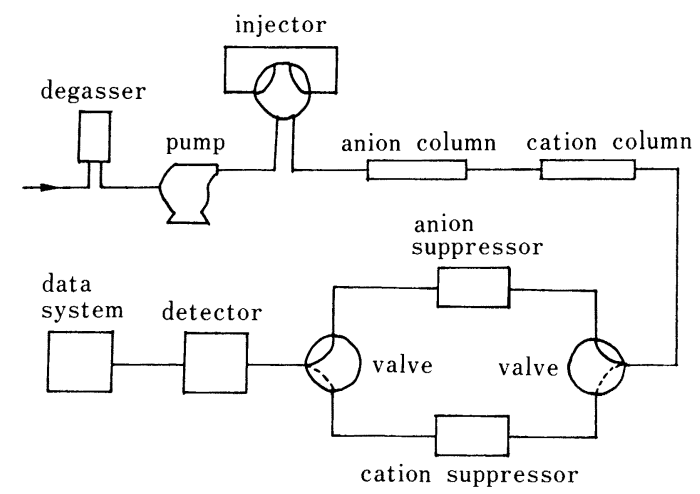

Fig. 1 Schematic diagram of IC apparatus for suppressor switching method
陰イオン交換膜型の陰イオンサプレッサー（横河電機 製，HPS-SC1）と陽イオン交換膜型の陽イオンサプレ ッサー（横河電機製， suppressor CX1）を並列に配置 し, 両サプレッサーの切り替えができるようなシステム を構成した．溶離液用の脱気装置としてはDEGASYS DG-1200（Uniflows 製）を用いた。横河 LC-100 デー 夕処理システムを用いてデータの取り込みと処理を行っ た。陰イオンサプレッサーを用いると，陽イオンは負の ピークとして検出されるため, 信号出力の極性を逆転さ せてデータ処理をした.

\section{$2 \cdot 3$ クロマトグラム条件}

最適分析条件は次のとおりである.陽イオン交換カラ ム ICS-C25 を陰イオン交換カラムSAM3-075 の後に 接続した。 カラム温度は $40^{\circ} \mathrm{C}$ に設定した。溶離液には $1.5 \mathrm{mM}$ シュウ酸 $(\mathrm{pH} 2.75)$ を用い, 流量を 0.8 $\mathrm{ml} / \mathrm{min}$ に設定した. 除去液は陰イオン分析に $10 \mathrm{mM}$ の硫酸, 陽イオン分析に $50 \mathrm{mM}$ の水酸化ナトリウムを 用い，除去液の流量をいずれも $1.0 \mathrm{ml} / \mathrm{min}$ に設定し た. 試料は $25 \mu \mathrm{l}$ を注入した. 実際試料の日本酒とワイ ンは $0.45 \mu \mathrm{m}$ メンブランフィルター (ミリポア製)で 沪過してイオン交換水で 5 倍又は 10 倍に希釈して注入 した.

\section{3 結果と考察}

\section{3・1 クロマトグラムとパラメーター}

陽イオン交換カラム（ICS-C25）を陰イオン交換力ラ ム（SAM3-075）の後に直結し，陰・陽イオン混合標準 溶液を注入したときのクロマトグラムを Fig. 2 に示し た. Fig. 2A はサプレッサーを外したときの, Fig. 2B は陽イオンサプレッサーを用いたときの, Fig. 2C は陰 イオンサプレッサーを用いたときのクロマトグラムを示 した。ノンサプレッサー方式（Fig. 2A）では, 陰イオ ンは正のピーク，陽イオンは負のピークとして, 同一ク ロマトグラム上に検出された。陽イオンサプレッサー方 式（Fig. 2B）では, 陽イオンが除去されて, 陰イオン のみが検出される。同様に陰イオンサプレッサ一方式 (Fig. 2C) では, 陰イオンが除去されて, 陽イオンのみ が検出される. Fig. 2A と Fig. 2B のクロマトグラムで 最初の 2 本の正のピークは注入された陽イオンに対态 する溶離液の電気伝導度変化を示している.

本法による陰・陽両イオンの分離に関するパラメー ターを Table 1 に示した. Table 1 に示すように, 陰イ オンは 40 分以内, 陽イオンは 35 分以内に浴出した. 2 本のカラム直列方法のテイリング係数はそれぞれ単独で 


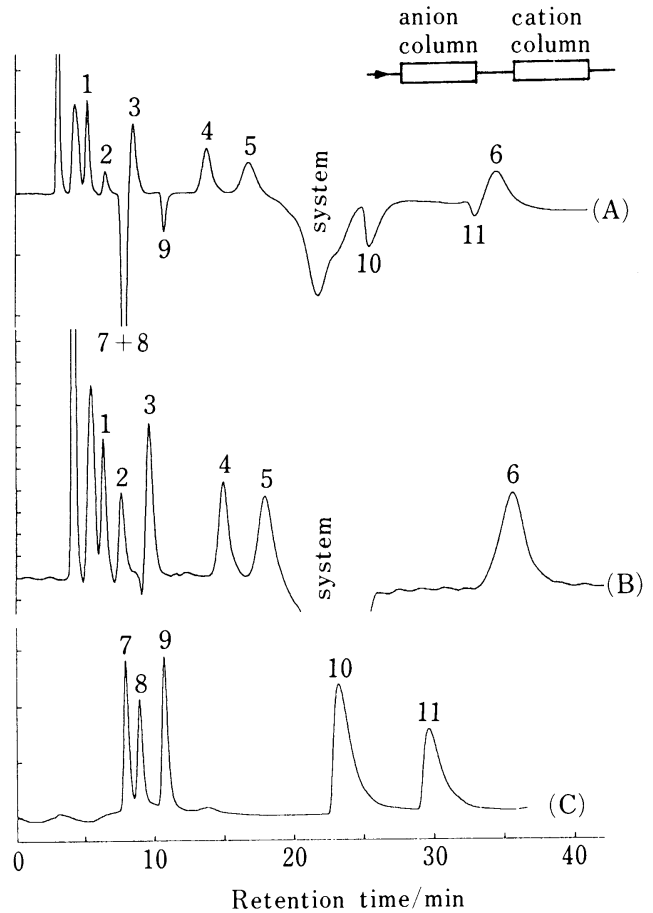

Fig. 2 Chromatograms of a mixture of anions and cations using (A) non-suppressor, (B) cation suppressor $\left(10 \mathrm{mM} \mathrm{H}_{2} \mathrm{SO}_{4}\right)$ and $(\mathrm{C})$ anion suppressor $(50 \mathrm{mM} \mathrm{NaOH})$

Temperature: $40^{\circ} \mathrm{C}$; Eluent: $1.5 \mathrm{mM}$ oxalic acid $(0.8 \mathrm{ml} / \mathrm{min})$; Injection volume: $25 \mu \mathrm{l}$. Peaks : $1=$ lactic acid, $2=$ formic, $3=$ malic, $4=\mathrm{H}_{2} \mathrm{PO}_{4}{ }^{-}$, $5=$ citric, $6=\mathrm{Cl}^{-}, 7=\mathrm{Na}^{+}, 8=\mathrm{NH}_{4}{ }^{+}, 9=\mathrm{K}^{+}, 10=$ $\mathrm{Mg}^{2+}, 11=\mathrm{Ca}^{2+}$

求めた值より大きい。これは試料イオンがカラム中で分 散するためと吸着を起こすためと考えられる. 理論段数 については, 陰イオンでは単独で求めた值より大きくな ったが，陽イオンではほぼ同じ值を示した。この結果よ り, 多少の疎水性を持つ有機酸は陽イオンカラムで疎水 性相互作用により分離能が向上されると考えられる.

\section{$3 \cdot 2$ 陰陽イオンの溶出特性}

陽イオン交換カラムの ICS-C25 を陰イオンカラムの SAM3-075 の後に接続し (Fig. 1), 陽イオン試料（塩 化物）を注入して得られたクロマトグラムを Fig. 3 に 示した. Fig. 3A に示したように, サプレッサーを外す と, 最初に 5 種類の陽イオンに対応して 2 本の正の ピークが現れた。 それぞれの陽イオンを単独で注入して
Table 1 Characteristics of serial columns on the elution of anions and cations

\begin{tabular}{lrcr}
\hline \multicolumn{1}{c}{ Ion } & $\begin{array}{c}\text { Retention } \\
\text { time/min }\end{array}$ & $\begin{array}{c}\text { Number of } \\
\text { theoretical } \\
\text { plates }\end{array}$ & $\begin{array}{l}\text { Tailing } \\
\text { factor }\end{array}$ \\
\hline Acetic & 5.60 & $1359(747)$ & $1.99(1.42)$ \\
Lactic & 6.33 & $1902(953)$ & $1.66(1.32)$ \\
Succinic & 6.46 & $1631(824)$ & $1.55(1.30)$ \\
Formic & 7.69 & $1562(1412)$ & $1.59(1.40)$ \\
Pyroglutamic & 9.22 & $1172(1251)$ & $1.45(1.13)$ \\
$\mathrm{Malic}^{-}$ & 9.64 & $1755(1118)$ & $1.72(1.20)$ \\
$\mathrm{H}_{2} \mathrm{PO}_{4}{ }^{-}$ & 14.91 & $2765(1521)$ & $1.34(1.01)$ \\
$\mathrm{Citric}$ & 17.94 & $1474(918)$ & $1.73(1.27)$ \\
$\mathrm{Tartaric}^{-}$ & 20.96 & - & - \\
$\mathrm{Cl}^{-}$ & 35.34 & 1943 & 0.93 \\
$\mathrm{Na}^{+}$ & 7.93 & $2375(2144)$ & $1.52(0.74)$ \\
$\mathrm{NH}_{4}{ }^{+}$ & 8.96 & $2585(2845)$ & $1.42(0.55)$ \\
$\mathrm{K}^{+}$ & 10.73 & $3275(4122)$ & $1.57(1.24)$ \\
$\mathrm{Mg}^{2+}$ & 23.58 & $1885(1799)$ & $2.98(3.64)$ \\
$\mathrm{Ca}^{2+}$ & 30.22 & $2892(2701)$ & $3.09(3.70)$ \\
\hline
\end{tabular}

The data obtained from each single column is shown in parentheses.

測定した結果，一番目の正のピーク (4.2 分) は 3 種類 の一価陽イオン $\left(\mathrm{Na}^{+}, \mathrm{NH}_{4}^{+}, \mathrm{K}^{+}\right)$に, 二番目の正 のピーク (5.5 分) は 2 種類の二価陽イオン $\left(\mathrm{Ca}^{2+}\right.$, $\mathrm{Mg}^{2+}$ ) に対応する. 続いて 5 種類の陽イオンはそれぞ れ 1 本の負のピークとして溶出した. 陽イオンサプレ ッサー (除去液: $10 \mathrm{mM} \mathrm{H}_{2} \mathrm{SO}_{4}$ ) を使うと, Fig. 3B に 示したように，5本の負のピークは消失したが，2 本の 正のピークは除去できなかった。陽イオンサプレッサー の代わりに，陰イオンサプレッサー（除去液： $50 \mathrm{mM}$ $\mathrm{NaOH}$ )を使うと，Fig. 3C に示したように，先に溶出 した 2 本の正のピークは最後に溶出した $\mathrm{Cl}^{-}$の正の ピークと一緒に除去され，5種類の陽イオンはそれぞれ 1 本のピークとして検出された.

陽イオン交換力ラム（ICS-C25）のみを使用しても上 記の現象が観察された。ICS-C25 カラムの充てん剂は カルボキシル基 (-COOH) を持つ弱酸性陽イオン交換 樹脂である. 実際には, 最初に溶出した 2 本の正の ピークは 5 種類の陽イオン（目的イオン）により陽イ オン交換樹脂の交換基から置き換えられた $\mathrm{H}^{+}$（溶出 オン）のピークである. $\mathrm{H}^{+}$が移動相に入ると, 溶離液 の電気伝導度は増加するので, 正のピークとして検出さ れる. 交換樹脂から陽イオンが溶出するとき, $\mathrm{Na}^{+}$, $\mathrm{NH}_{4}{ }^{+}, \mathrm{K}^{+}, \mathrm{Ca}^{2+}, \mathrm{Mg}^{2+}$ より当量電気伝導度の大き い $\mathrm{H}^{+}$が当量的に交換樹脂と結合するので, 溶離液の 電気伝導度は減少して, 陽イオンは負のピークとして検 


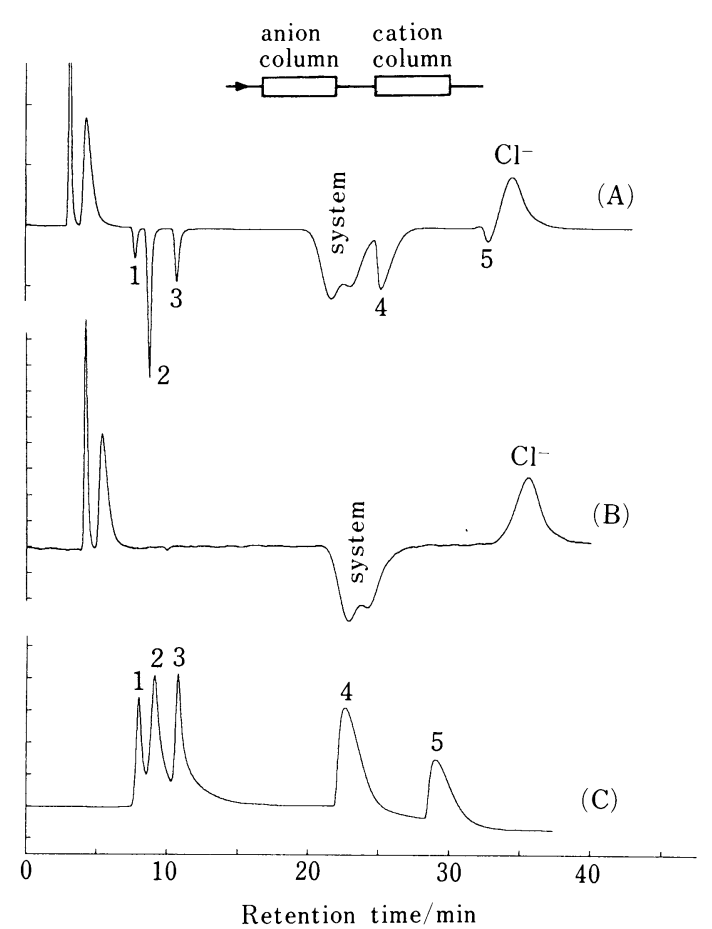

Fig. 3 Chromatograms of a mixture of cations (chloride)

(A) non-suppressor, (B) cation suppressor, (C) anion suppressor. Conditions are the same as those in Fig. 2. Peaks: $\mathrm{l}=\mathrm{Na}^{+}, \quad 2=\mathrm{NH}_{4}{ }^{+}, 3=\mathrm{K}^{+}, \quad 4=$ $\mathrm{Mg}^{2+}, 5=\mathrm{Ca}^{2+}$

出される. ICS-C25 カラムではアルカリ金属は陽イオ ン交換反忘により溶出されるのに対し，アルカリ土類金 属は陽イオン交換反応と溶離液（錯形成能力をもつ有機 酸）との錯形成による配位子交換反応が組み合わされて 溶出する7)。それゆえ，二価陽イオンは一価陽イオンよ り交換樹脂との交換反忘が遅いので，一価と二価の陽 オンに対応して置き換えられた $\mathrm{H}^{+}$は 2 本のピークに 分かれて溶出した。溶出イオンの $\mathrm{H}^{+}$は陰イオンサプ レッサーを通すと水酸化ナトリウム除去液よりの $\mathrm{OH}^{-}$ と反応し, 中和されるので, 溶出イオンのピークは消失 する.

\section{$3 \cdot 3$ カラム接続順序}

陰・陽イオン交換カラムを值結すると, カラムの接続 順序によって，陽イオンの溶出特性に違いが見られた。 各陰イオン (無機陰イオンと有機酸) は陰・陽イオンカ ラムの接続順序と関係なく，単一カラムと同じようにほ

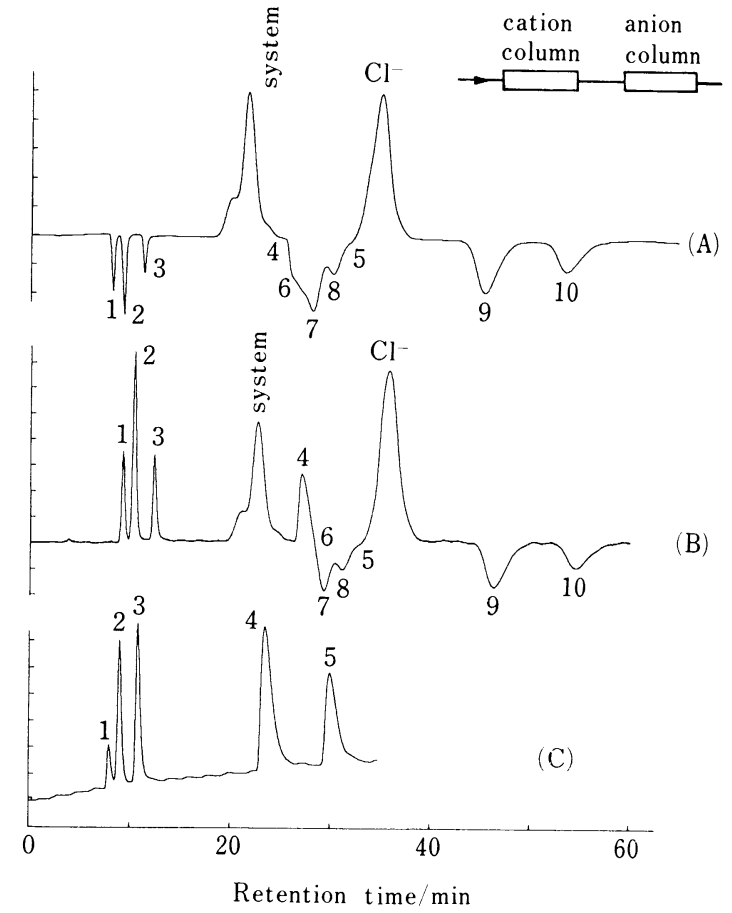

Fig. 4 Chromatograms of a mixture of cations (chloride)

(A) non-suppressor, (B) cation suppressor, (C) anion suppressor. Conditions are the same as those in Fig. 2. Peaks: $1 \& 6=\mathrm{Na}^{+} ; 2 \& 7=\mathrm{NH}_{4}{ }^{+} ; 3 \&$ $8=\mathrm{K}^{+} ; 4 \& 9=\mathrm{Mg}^{2+} ; 5 \& 10=\mathrm{Ca}^{2+}$

ぼ一定の位置にそれぞれ1本の正のピークとして溶出 し，陰イオンサプレッサーで除去できる。

陰・陽イオンカラムの接続順序を逆にする，すなわ ち, 陰イオンカラムの SAM3-075 を陽イオンカラムの ICS-C25 の後に直結すると, Fig. 4 に示したクロマト グラムが得られた. Fig. 4A はサプレッサーを使わない ときの, Fig. 4B は陽イオンサプレッサーを用いたとき の, Fig. 4C は陰イオンサプレッサーを用いたときのク ロマトグラムである.

Fig. 4A に示したように, 各陽イオンに対して 2 本の ピークが現れた。これは，陽イオンカラムで分離された 各陽イオンが陰イオンカラムに入ると，陰イオンカラム での目的イオンと溶出イオンの移動速度が異なり, 目的 イオンの溶出位置と目的イオンの溶出に伴う㴶出イオン の減少位置とに差が生じるためと考えられる ${ }^{8} . \mathrm{H}^{+}$が 陰イオンカラムに入ると, 


$$
\mathrm{H}^{+}+\underset{\mathrm{COOH}}{\mathrm{COO}^{-}} \rightleftharpoons \begin{gathered}
\mathrm{COOH} \\
\mathrm{COOH}
\end{gathered}
$$

の平衡が成り立ち, 検出時に平衡が右にずれた分だけ電 気伝導度が減少するため, 負の溶出イオンピークを与え るものと考えられる. Fig. 4B に示したように，陽イオ ンサプレッサーを使うと目的イオンのピークは正のピー クになって残った。目的イオンピークの反転はサプレッ サーでのイオンの存在状態の変化に起因すると考えられ る. Fig. 4C に示したように, 陰イオンサプレッサーを 通すと, 溶出イオンのピークは消えて, 5 種類の陽イオ ンはそれぞれ 1 本のピークとして検出された。

以上のことより，陽イオン交換カラムを先に直結する 方法は実際に応用する際にクロマトグラムを複雑にする ので，不適当であると判明した。

\section{$3 \cdot 4$ 検出限界}

最適分析条件下で, 7 種類の陰イオンと 5 種類の陽イ オンの検出限界之検量線の直線性について検討した結果 をTable 2 に示した．検出限界はノイズの大きさ (ベースラインの幅）と適当に希釈した各成分のピーク 高さ $(S / N=3)$ より計算した. Table 2 より明らかな ように, 検量線の直線範囲は二けた以上で, 食品分析に 十分である。検討した濃度範囲ではそれぞれの試料イオ ンにおいて直線性相関係数 $\left(r^{2}\right)$ が 0.998 から 1.000 を 示し，良好な值線性があることが判明した。検出限界に ついては, 陰イオンは $0.2 \sim 0.9 \mathrm{ppm}$ で, 単一カラム法

Table 2 Detection limits and linear range of tested anions and cations

\begin{tabular}{lcc}
\hline & $\begin{array}{c}\text { Detection limit } \\
\text { ppm }\end{array}$ & $\begin{array}{c}\text { Linear range }^{\dagger \dagger}, \\
\text { ppm }\end{array}$ \\
\hline Lactic & $0.9(0.5)$ & \\
Formic & $0.5(0.1)$ & $4 \sim 540(4 \sim 1080)$ \\
Pyroglutamic & $0.6(0.2)$ & $8 \sim 800(4 \sim 2000)$ \\
Malic & $0.5(0.3)$ & $16 \sim 800(4 \sim 2000)$ \\
$\mathrm{H}_{2} \mathrm{PO}_{4}{ }^{-}$ & $0.3(0.1)$ & $4 \sim 200(2 \sim 1000)$ \\
$\mathrm{Citric}$ & $0.2(0.1)$ & $4 \sim 200(1 \sim 500)$ \\
$\mathrm{Tartaric}_{\mathrm{Cl}}{ }^{+}$ & 0.2 & $8 \sim 200$ \\
$\mathrm{Na}^{+}$ & 0.4 & $10 \sim 400$ \\
$\mathrm{NH}_{4}{ }^{+}$ & $0.0008(0.006)$ & $0.3 \sim 43(0.4 \sim 85)$ \\
$\mathrm{K}^{+}$ & $0.002(0.006)$ & $0.4 \sim 40(1.6 \sim 200)$ \\
$\mathrm{Mg}^{2+}$ & $0.001(0.02)$ & $0.3 \sim 40(1.6 \sim 200)$ \\
$\mathrm{Ca}^{2+}$ & $0.002(0.01)$ & $0.3 \sim 43(1.7 \sim 210)$ \\
\hline
\end{tabular}

$\dagger S / N=3 ; \quad \dagger \dagger$ by peak area. The data obtained from each single column is shown in parentheses.
より若干高い。陽イオンは $0.8 \sim 8 \mathrm{ppb}$ で，単一カラム 法より数倍小さい。ここで, ノイズの大きさ (ベースラ インの幅）は検出限界に大きい影響を与えた。陽イオン サプレッサーを通す陰イオン分析流路では大きいノイズ を生じるのに対し，陰イオンサプレッサーを通す陽イオ ン分析流路ではより小さいノイズを示した。陰イオン分 析用の硫酸除去液の濃度は濃くすればするほど, ノイズ が大きくなった。

\section{$3 \cdot 5$ 本法による日本酒とワイン中の陰陽イオンの定}

日本酒には $\mathrm{Na}^{+}, \mathrm{NH}_{4}{ }^{+}$, リンゴ酸が共存している ので，ノンサプレッサー方式の適用は困難である. 本法 のサプレッサー切り替え方式を採用すると，日本酒のよ うな飲物中の有機酸と陽イオンの同時定量が達成でき る.

本法を用いて日本酒とワイン中の陰・陽イオンの定量 を行った．陽イオンサプレッサーを用いて得られた日本 酒とワイン中の陰イオンのクロマトグラムを Fig. 5

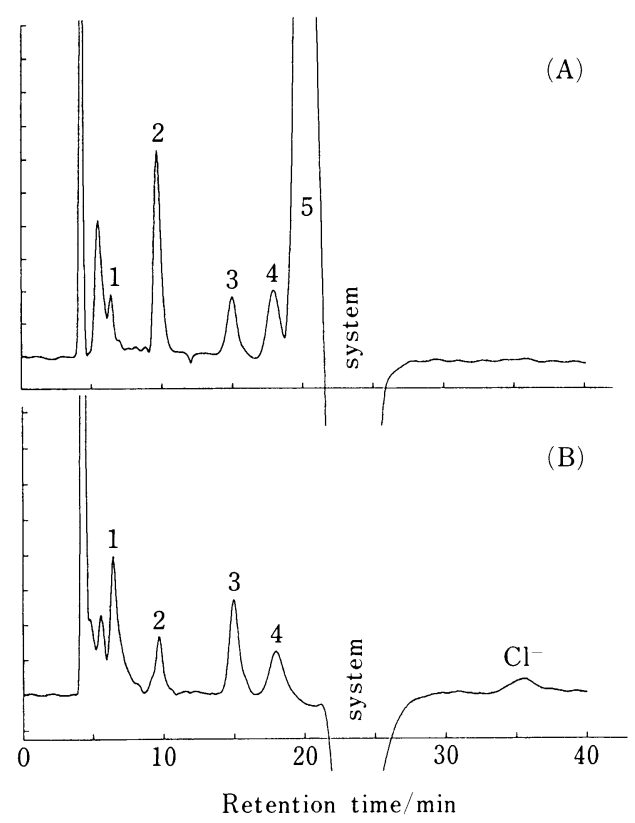

Fig. 5 Chromatograms of anions in (A) white wine (Koshu 1988) and (B) Japanese sake using a cation suppressor with 10 -fold dilution

Peaks: $1=$ lactic acid, $2=$ malic, $3=\mathrm{H}_{2} \mathrm{PO}_{4}{ }^{-}$, $4=$ citric, $5=$ tartaric. Conditions are the same as those in Fig. 2. 

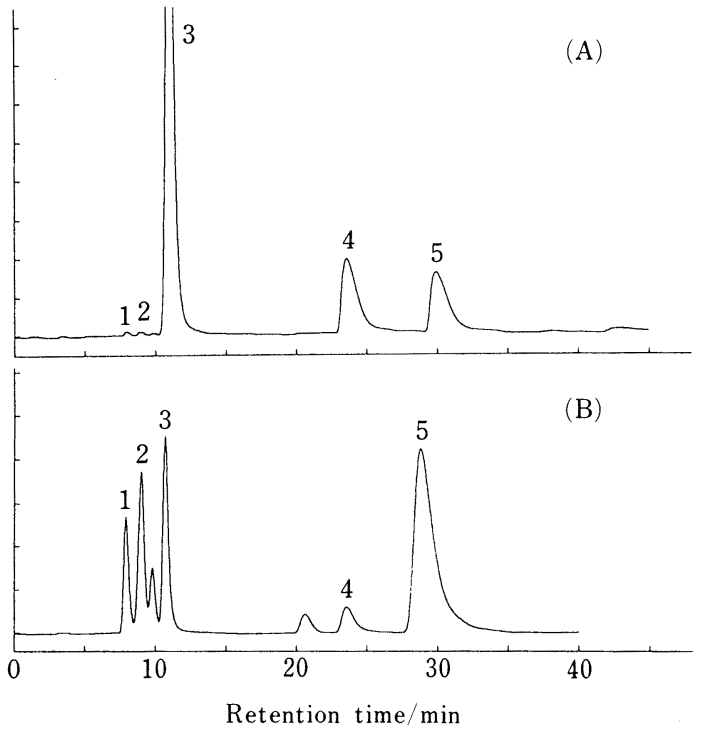

Fig. 6 Chromatograms of cations in (A) white wine (Koshu 1988) and (B) Japanese sake using an anion suppressor with $10^{-}$-fold dilution

Peaks: $\mathrm{l}=\mathrm{Na}^{+}, 2=\mathrm{NH}_{4}{ }^{+}, 3=\mathrm{K}^{+}, 4=\mathrm{Mg}^{2+}, 5=$ $\mathrm{Ca}^{2+}$. Conditions are the same as those in Fig. 2.

に，陰イオンサプレッサーを用いて得られた日本酒とワ イン中の陽イオンのクロマトグラムを Fig. 6 に示し た。

ピーク面積検量線法を用いた日本酒とワイン中に存在 する主要な有機酸と陽イオン及び無機陰イオンの定量結 果はTable 3 に記載した. Table 3 に示したように，良 好な定量精度があり，相対標準偏差（RSD）は $0.72 \%$ から $5.03 \%$ までの範囲であった。

陰イオンの定量の場合には, 日本酒とワイン中に通常 含まれるコハク酸と乳酸はほぼ同じ時間（それぞれ 6.46 分と 6.33 分）で溶出するため,この両成分は合量 として定量される。 又, 酢酸は $\mathrm{Ca}^{2+}$ と $\mathrm{Mg}^{2+}$ に対応 する溶出ピーク（Fig. 2A の 2 番目の正のピーク）に隠 れて定量できない. ワインのような, 酒石酸を大量に含 有する試料では, 酒石酸のピークが直後のシステムピー クと部分的に重なり (Fig. 5A), 酒石酸定量に誤差を生 ずる. Table 3 に示した白ワイン (甲州 1988) 中の酒 石酸の定量結果 $(2016 \mathrm{ppm})$ はフタル酸水素カリウム 溶離液を用いた単一カラム法4)（1524 ppm）より大き い.これは, 酒石酸は酒石酸モノカリウム塩（酒石）と してワイン中で沈殿するため, 保存温度によって濃度が
Table 3 Analytical results $(n=5)$ of anions and cations in beverages by serial column method

\begin{tabular}{|c|c|c|c|}
\hline & \multicolumn{3}{|c|}{ Average, ppm (RSD, \%) } \\
\hline & White wine & $\begin{array}{c}\text { Japanese } \\
\text { sake l }\end{array}$ & $\begin{array}{c}\text { Japanese } \\
\text { sake } 2\end{array}$ \\
\hline Formic & $16.8(4.71)$ & & \\
\hline Pyroglutamic & $33.7(5.03)$ & & \\
\hline Malic & $2894 \quad(1.21)$ & $223.0(1.06)$ & $257.1(2.02)$ \\
\hline $\mathrm{H}_{2} \mathrm{PO}_{4}^{-}$ & $384.0(1.41)$ & $280.0(1.31)$ & $271.9(1.59)$ \\
\hline Citric & $392.5(1.84)$ & $63.5(2.52)$ & $90.3(2.48)$ \\
\hline Tartaric & $2016 \quad(4.95)$ & & \\
\hline $\mathrm{Cl}^{-}$ & & $45.9(4.20)$ & $36.2(2.28)$ \\
\hline $\mathrm{Na}^{+}$ & & $7.8(4.26)$ & $22.5(1.16)$ \\
\hline $\mathrm{NH}_{4}{ }^{+}$ & & $49.5(1.23)$ & $75.0(2.89)$ \\
\hline $\mathrm{K}^{+}$ & $612.8(0.72)$ & $58.1(1.26)$ & $67.4(0.90)$ \\
\hline $\mathrm{Mg}^{2+}$ & $68.1(1.48)$ & $8.0(1.96)$ & $9.4(2.83)$ \\
\hline $\mathrm{Ca}^{2+}$ & $87.0(1.00)$ & $80.3(1.23)$ & $131.5(1.65)$ \\
\hline
\end{tabular}

変化したと考えられる.

本研究では陰・陽イオン交換カラムを直結し, 陰・陽 イオンサプレッサーの切り替えにより陰・陽イオンの同 時分析を行った。同じ溶離液を用いてアルコール飲料中 の主要な陰・陽イオンの同時定量ができる. 残念なが ら, 酢酸は $\mathrm{Ca}^{2+}$ と $\mathrm{Mg}^{2+}$ に対念する溶出イオンの ピークに隠れ，乳酸とコハク酸は重なるので，この 3 種類の有機酸は本法で定量できない。

\section{文献}

1) 日本分析化学会編：“イオンクロマトグラ フィ一”, (1989)，(共立出版).

2) イオンクロマトグラフィ一研究懇談会編: “イオ ンクロマトグラフィー・データブック”, (1991), (科学新聞社).

3）武藤義一, 及川紀久雄編: “イオンクロマトグラフ イ一”,(1983)，(講談社).

4）鈴木義仁, 小泉 均, 谷 和江, 丁 明玉: 分析化 学, 40, T15 (1991).

5）鈴木義仁, 丁 明玉, 小泉 均: 第 8 回イオンク ロマトグラフィーフォーラム講演要旨集, p. 40 (1991).

6）丁 明玉, 鈴木義仁, 小泉 均: 分析化学, 42,49 (1993).

7) 熊谷浩樹, 飯沢はるみ, 井上嘉則: 第 7 [以1イン クロマトグラフィーフォーラム講演要旨集, p. 10 (1990).

8) 西村雅之, 林 守正, 川崎敦子: 第 52 回分析化学 討論会講演要旨集, p. 435 (1991). 
Selective detection using a suppressor switching technique for anions and cations in beverages by ion chromatography. Mingyu Ding, Yoshihito Suzuki and Hitoshi Korzum (Department of Chemistry and Biotechnology, Faculty of Engineering, Yamanashi University, 4-3-11, Takeda, Kofu-shi, Yamanashi 400)

A suppressor switching method was studied for the simultaneous determination of organic acids and cations in beverages by ion chromatography with $1.5 \mathrm{mM}$ oxalic acid (flow rate $0.8 \mathrm{ml} / \mathrm{min}$ ) as an eluent which can be used for the separation of anions and cations. An anion exchange column (Yokogawa SAM3-075, $4.9 \mathrm{~mm}$ i.d. $\times 75 \mathrm{~mm}$ ) and a cation exchange column (Yokogawa ICS-C25, $4.6 \mathrm{~mm}$ i.d. $\times 125 \mathrm{~mm}$ ) were connected in series. An anion suppressor and a cation suppressor were connected in parallel so that the selection of flow could be made for cations and anions. When the effluent from the columns flows through a cation suppressor of a cation exchange membrane type, the cations were suppressed and only anions were detected. If the flow of effluent from columns is changed to anion suppressor by valves, only cations were detected. The main anions (organic acids and inorganic anions) in beverages were separated at $40^{\circ} \mathrm{C}$ within $40 \mathrm{~min}$ when $10 \mathrm{mM}$ sulfuric acid at a flow rate of $1.0 \mathrm{ml} / \mathrm{min}$ was used as a regenerant for cations. The cations $\left(\mathrm{Na}^{+}, \mathrm{NH}_{4}{ }^{+}, \mathrm{K}^{+}, \mathrm{Mg}^{2+}, \mathrm{Ca}^{2+}\right)$ were eluted at $40^{\circ} \mathrm{C}$ within 35 min when $50 \mathrm{mM} \mathrm{NaOH}$ was used as a regenerant for anions. This method was applied to the determination of both anions and cations in wine and Japanese sakes with a good reproducibility.

(Received December 14, 1992)

\section{Keyword phrases}

suppressor switching method; ion chromatography of organic acids and cations; serial connection of anion and cation exchange column. 